\title{
CCL2/CCR2 and CX3CL1/CX3CR1 chemokine axes and their possible involvement in age-related macular degeneration
}

\author{
William Raoul ${ }^{1,2,3}$, Constance Auvynet ${ }^{1,2,3,4}$, Serge Camelo ${ }^{1,2,3}$, Xavier Guillonneau ${ }^{1,2,3}$, Charles Feumi ${ }^{1,2,3}$, \\ Christophe Combadière ${ }^{4,5,6^{*}+}$, Florian Sennlaub ${ }^{1,2,3,7^{*+}}$
}

\begin{abstract}
The causes of age-related macular degeneration (AMD) are not well understood. Due to demographic shifts in the industrialized world a growing number of people will develop AMD in the coming decades. To develop treatments it is essential to characterize the disease's pathogenic process. Over the past few years, numerous studies have focused on the role of chemotactic cytokines, also known as chemokines. Certain chemokines, such as CCL2 and CX3CL1, appear to be crucial in subretinal microglia and macrophage accumulation observed in AMD, and participate in the development of retinal degeneration as well as in choroidal neovascularization. This paper reviews the possible implications of CCL2 and CX3CL1 signaling in AMD. Expression patterns, single nucleotide polymorphisms (SNPs) association studies, chemokine and chemokine receptor knockout models are discussed. Future AMD treatments could target chemokines and/or their receptors.
\end{abstract}

\section{Introduction}

Age-related macular degeneration (AMD) is the leading cause of legal blindness in the developed world [1]. The pathology is characterized by lesions of photoreceptors, retinal pigment epithelium (RPE), Bruch's membrane (BM) and choriocapillaris [2]. Physiologically, the RPE phagocytoses, degrades and recycles photoreceptor outer segments, and clears the debris through the underlying BM into the choroidal circulation. RPE cells selectively transport nutrients from the choroidal capillaries to the outer retina (external hemato-retinal barrier). In the early stages of AMD changes in RPE pigmentation and the excessive presence of yellowish-white subretinal deposits called drusen are clinically observable (fundoscopy) $[2,3]$. Drusen are composed of lipids and proteins [4], located on the BM, they are partially covered by the RPE. It is believed that drusen are formed because of a

\footnotetext{
* Correspondence: christophe.combadiere@upmc.fr; florian.sennlaub@inserm. $\mathrm{fr}$

+ Contributed equally

${ }^{1}$ INSERM, UMR S 872, Centre de Recherche des Cordeliers, F-75006, Paris, France

${ }^{4}$ INSERM, UMR_S945, Laboratoire d'Immunologie Cellulaire, F-75013, Paris, France

Full list of author information is available at the end of the article
}

transport defect between the RPE and the choriocapillaries or as a result of degenerating RPE cells [5]. There are two clinical forms of late AMD: the fast progressing exudative form defined by choroidal neovascularisation, responsible for the majority of legal blindness in AMD, and the more slow progressing atrophic form characterized by RPE atrophy, photoreceptor degeneration and choroidal involution and obliteration [6,7]. Some of these features can be simulated in a variety of animal models [8], but no animal model has consistently reproduced AMD.

In recent years, there has been increasing evidence for an inflammatory component in AMD. Drusen deposits have been reported to contain immune complexes, complement factors, major histocompatibility complex (MHC) and amyloid oligomers, among others [5,9-12]. A more recent discovery, that AMD is associated with a polymorphism of complement factor $\mathrm{H}(\mathrm{CfH})$ [13-15], a polymorphism that leads to an overactivation of the complement system $[16,17]$, emphasizes the importance of inflammatory mediators in AMD. Nevertheless, it remains unclear how the over-activation of the complement system leads to AMD.

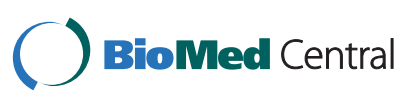

(c) 2010 Raoul et al; licensee BioMed Central Ltd. This is an Open Access article distributed under the terms of the Creative Commons Attribution License (<url>http://creativecommons.org/licenses/by/2.0</url>), which permits unrestricted use, distribution, and reproduction in any medium, provided the original work is properly cited. 
Microglial cells (MC) are the resident macrophages of the central nervous system (CNS). In the eye they are only located in the inner retina $[18,19]$. The subretinal space is physiologically devoid of MCs or macrophages $(\mathrm{M} \varphi)$ in healthy young adult subjects. In AMD, MC and $\mathrm{M} \varphi$ are activated $[9,20]$ and accumulate in the subretinal space $[19,21]$. Interestingly, activated complement fraction C3 and C5 participate in neutrophil and macrophage recruitment to the subretinal space in a choroidal neovascularization model [22]. A similar mechanism might participate in retinal/choroidal inflammation in AMD. The prolonged presence of $\mathrm{MC} / \mathrm{M} \varphi$ in the subretinal space is associated with photoreceptor degeneration $[19,23]$ and the development of choroidal neovascularization in animal models $[24,25]$. This is possibly because $\mathrm{MC} / \mathrm{M} \varphi$ are an important source of cytokines and angiogenic factors like VEGF [26,27]. Interfering with subretinal $\mathrm{MC} / \mathrm{M} \varphi$ accumulation might therefore be a promising avenue in the treatment of AMD, but the mechanisms of subretinal $M C / M \varphi$ cell accumulation remain unclear.

Chemokines constitute a family of structurally related chemotactic cytokines that direct the migration of leukocytes throughout the body, both under physiological and pathological conditions [28]. CCL2 signaling through CCR2, and CX3CL1 signaling through CX3CR1 are key factors in $M \varphi$ recruitment to a tissue lesion $[29,30]$. In this review, we discuss the possible role of CCL2/CCR2 and $\mathrm{CX} 3 \mathrm{CL} 1 / \mathrm{CX} 3 \mathrm{CR} 1$ axes in $\mathrm{MC} / \mathrm{M} \varphi$ homeostasis in the healthy eye and in AMD. We review data describing the expression of these chemokines and their receptors in the retina, polymorphism studies in AMD, animal chemokine and chemokine receptor knockout models presenting drusen formation, and photoreceptor degeneration or choroidal neovascularisation.

CX3CL1, CX3CR1, CCR2 and CCL2 expression in the retina In the blood, chemokine receptors CCR2 and CX3CR1 identify two functional subsets of murine blood monocytes: "inflammatory" monocytes, which express both receptors, and non-inflammatory monocytes, which only express CX3CR1 [31]. CCL2 and CX3CL1 released by tissue lesions participate in the recruitment of monocytes and in local inflammation $[29,30]$.

CX3CL1 is an atypical chemokine. It is expressed as a transmembrane protein, which can be cleaved by proteases into a soluble form that has chemotactic properties [32]. In its transmembrane form, CX3CL1 mediates integrine-like intracellular adhesion. Unlike many promiscuous chemokines, it only signals through the CX3CR1 receptor [33]. In the eye, it is constitutively expressed in retinal neurons and in the RPE [34] CX3CL1 can also be induced in microvascular endothelial cells [34]. In the retina, the vast majority of resident "quiescent" $\mathrm{MCs}$ express CX3CR1 in newborn (PN6) and adult mice (6 to 18 months) $[19,35]$. Immunohistochemistry reveals similar results in humans [19]. Contrary to a previous report, the use of CX3CR1-specific antibody in humans and experiments with $\mathrm{Cx} 3 \mathrm{cr} 1^{\mathrm{GFP} /+}$ mice [36] failed to find significant CX3CR1 expression in RPE cells in vivo [37]. MCs are the only cells in the retina that express CX3CR1 under physiological conditions.

CCL2 expression in the retina and RPE is very low in healthy young adult animals [38], but increases in acute inflammation $[23,39,40]$, with aging [38] and under oxidative stress in the RPE [41].

Recent evidence suggests that subretinal $\mathrm{MC} / \mathrm{M} \varphi$ induce CCL2 and CCL5 in the RPE [42]. CCL2 mainly signals through CCR2 [43]. There is no direct evidence of CCR2 expression by retinal MCs or macrophages in the retina. However, it has been shown that CCL2/ CCR2 signaling is involved in monocyte or MC recruitment after laser injury [44,45] and aging [45] in knockout mice. This suggests that CCR2-expressing monocytes or MCs are present at some point in these models. In the brain, CCR2 expression has been reported to be very low in healthy rat CNS microglia, but large numbers of CCR2 positive $\mathrm{MC} / \mathrm{M} \varphi$ are found in acute inflammation [46]. To summarize, CX3CL1 and CX3CR1 are constitutively and robustly expressed in the retina and might have a role in retinal homeostasis. In contrast, CCL2 is expressed at low levels in the healthy young adult, but increases with age and injury. A very recent clinical study shows that elevated intraocular CCL2 levels are associated with exudative AMD [47]. CCL2 might therefore play a role in monocyte and microglial cell recruitment to the subretinal space with age and in AMD.

\section{CX3CR1, CCR2 and CCL2 single nucleotide polymorphisms (SNPs) AMD}

Several studies have examined SNPs of the chemokine system and AMD susceptibility. The T280M allele of the CX3CR1 gene has been shown to be associated with AMD in a group of Caucasian patients recruited in the Washington D.C. area [37]. We replicated this association in a group of $\mathrm{C}$-aucasian patients recruited in Paris [19] and a similar association has recently been found in Han Chinese patients recruited in Nantong [48]. Previous studies show that the M280 polymorphism provokes loss of chemotaxis [49] or increases adherence to its ligand [50]. Therefore, dysfunctional CX3CL1/ CX3CR1 signaling might play a role in AMD (see below). No evidence was found of an association between common genetic variations of CCR2, and CCL2 and AMD [51]. 


\section{The $\mathrm{C} \times 3 \mathrm{Cr}^{-1-}$ mouse model of AMD}

As the T280M allele of the CX3CR1 leads to dysfunctional monocyte migration [19] and is associated with AMD $[19,37,48]$, several groups have studied Cx3 $\mathrm{cr}^{-1-}$ mice to decipher the effect of CX3CR1 dysfunction on ocular homeostasis. As with monocytes bearing the T280M allele, Cx3 $\mathrm{Cr}^{-1-}$ MCs display inhibited migration [52] when compared with CX3CR1 competent MCs. We have shown that $\mathrm{Cx} 3 \mathrm{cr}^{-1-}$ mice spontaneously accumulate subretinal $\mathrm{MC} / \mathrm{M} \varphi$ with age in the absence of photoreceptor degeneration [19]. Furthermore, an increased accumulation of subretinal $\mathrm{MC} / \mathrm{M} \varphi$ is found after light injury in comparison to a wildtype control group [53]. These results stand in sharp contrast to observations of inflamed peripheral tissue, where $\mathrm{Cx} 3 \mathrm{Cr}^{-1-}$ mice similar to other chemokine receptor knockouts present an inhibition of $M \varphi$ accumulation [30].

It has since been recognized that subretinal $\mathrm{MC} / \mathrm{M} \varphi$ also accumulate in wild type mice at a more advanced age [54], suggesting that dysfunction of certain chemokines and possible other factors accelerates a physiological process leading to $\mathrm{MC} / \mathrm{M} \varphi$ accumulation at an earlier age in $\mathrm{Cx} 3 \mathrm{Cr}^{-1-}$ mice as compared to controls. $\mathrm{Ng}$ et al. [55] showed that normal animal facility lighting conditions induced subretinal $\mathrm{MC} / \mathrm{M} \varphi$ accumulation in the absence of photoreceptor degeneration in albino strains. Furthermore they show that subretinal MC/M $\varphi s$ are cleared from the subretinal space when light stimulus is removed. These observations suggest that $\mathrm{MC} /$ M $\varphi$ s migrate to the subretinal space and are subsequently cleared once the stimulus is removed in the absence of primary pathological photoreceptor or RPE lesions. It remains unclear if this clearance is due to apoptosis of the subretinal $\mathrm{MC} / \mathrm{M} \varphi$ or to migration from the subretinal space. In retinal degeneration, where severe degeneration occurs, we observed an egress of rhodopsin laden $\mathrm{MC} / \mathrm{M} \varphi$ s from the subretinal space [53], suggesting that $\mathrm{MC} / \mathrm{M} \varphi \mathrm{s}$ can leave the subretinal space by migration. The migratory deficit observed in $\mathrm{Cx} 3 \mathrm{Cr}^{-1-}$ microglia [52] might contribute to the reduced clearance from the subretinal space and therefore accelerate the accumulation, as observed in aged $\mathrm{Cx} 3 \mathrm{cr}^{-/-}$ mice. Nevertheless, it cannot be excluded that reduced subretinal $\mathrm{MC} / \mathrm{M} \varphi$ apoptosis plays a role in subretinal $\mathrm{MC} / \mathrm{M} \varphi$ accumulation.

In $\mathrm{Cx} 3 \mathrm{Cr}^{-1-}$ mice, the resulting prolonged presence of subretinal $\mathrm{MC} / \mathrm{M} \varphi$ in the subretinal space is associated with excessive OS phagocytosis by the $\mathrm{MC} / \mathrm{M} \varphi \mathrm{s}$, which subsequently ingest intracellular lipids $[19,56]$. These subretinal MC/M $\varphi$ "foam cells" are the origin of the drusen-like deposits observed in the clinical observation of $\mathrm{C} \times 3 \mathrm{Cr}^{-1 /}$ mice [19] and have recently been reported in $\mathrm{Ccl}^{-1-}$ mice [45] (see below). Similarly, CX3CR1- positive bloated subretinal microglial cells are found in the eyes of AMD patients [19,21]. Recent reports suggest that drusen appearance in patients with AMD is not solely caused by sub-RPE deposits, but also by subretinal drusenoid deposits [57-59] not unlike the lesions observed in $\mathrm{Cx} 3 \mathrm{Cr}^{-1-}$ and $\mathrm{Ccl} 2^{-1-}$ mice. It is tempting to speculate that these drusenoid deposits are the consequence of accumulated debris from subretinal $\mathrm{MC} / \mathrm{M} \varphi$ "foam cell" apoptosis. In consequence, drusen might evolve from subretinal deposits which are subsequently covered by the RPE. There are several lines of evidence supporting this hypothesis: drusen contain numerous degenerating organelles, the origin of which may be subretinal MC/M $\varphi$ [4]. Moreover, drusen contain CX3CR1, apolipoprotein $\mathrm{E}$, complement factors, and the major histocompatibility complex (MHC) [5,9-12,19], all of which can be expressed by MC/M $\varphi$ [19,60-62]. The debris and inflammatory proteins found in drusen may originate in part from $\mathrm{MC} / \mathrm{M} \varphi$ additionally to $\mathrm{RPE}$ debris.

Another consequence of the prolonged presence of $\mathrm{C} \times 3 \mathrm{cr}^{-1-} \mathrm{MCs}$ in the subretinal space is photoreceptor cell death $[19,53]$ and changes in RPE structure and distribution [42]. In $\mathrm{Cx}_{3} \mathrm{cr}^{-1-}$ mice on a pigmented C57Bl6 background, photoreceptor degeneration of about 25$30 \%$ is observed in 18-month-old mice as compared to wild type C57BL6 mice and can be induced in twomonth-old $\mathrm{Cx} 3 \mathrm{Cr}^{-1-}$ mice by exposure to $100 \mathrm{Klux}$ for $10 \mathrm{~min}$, which does not provoke degeneration in wild type C57BL6 mice $[19,53]$. Cx3 $\mathrm{cr}^{-1-}$ mice on an albino Balb genetic background develop complete light-dependent photoreceptor degeneration by the age of four months in $12 \mathrm{~h} / 24 \mathrm{~h} \mathrm{100-500} \mathrm{lux} \mathrm{(normal} \mathrm{animal} \mathrm{facility}$ conditions). In a light-induced model that provokes near complete degeneration in pigmented C57Bl6 wild type animals this difference is no longer observed [63], suggesting that a maximal $\mathrm{MC} / \mathrm{M} \varphi$ cell toxicity can be reached in wild type animals. Activated MC toxicity has been shown in photoreceptors in vitro [64] and in vivo [23]. Neuronal cell toxicity caused by the prolonged presence of activated $\mathrm{Cx} 3 \mathrm{cr}^{-1-} \mathrm{MCs}$ in the brain has been described as a mechanism of neurodegenerative diseases [65]. Similar mechanisms may cause the degeneration observed in the $\mathrm{Cx} 3 \mathrm{Cr}^{-1-}$ mice.

Additionally, $\mathrm{Cx} 3 \mathrm{Cr}^{-1-}$ mice develop increased $\mathrm{MC} /$ $\mathrm{M} \varphi$ accumulation and choroidal neovascularization in comparison to controls in a laser-induced choroidal neovascularization (CNV) model, suggesting that the presence of subretinal $\mathrm{MC} / \mathrm{M} \varphi \mathrm{s}$ contributes to a proangiogenic environment [19]. MC/M $\varphi s$ might produce proangiogenic factors themselves, but more importantly, they have been shown to induce MMP9 and VEGF expression in the RPE [42]. This may help to explain the increase in $\mathrm{CNV}$ observed in $\mathrm{Cx} 3 \mathrm{crr}^{-1-}$ mice. 
In summary, $\mathrm{Cx} 3 \mathrm{Cr}^{-1-}$ mice develop primary subretinal $\mathrm{MC}$ accumulation, possibly resulting from a migratory defect associated with CX3CR1 dysfunction. We have shown that the M280 polymorphism of CX3CR1, associated with AMD increases adherence to its ligand [50]. The increased adherence to transmembraneous CX3CL1 abundantly present in the retina and RPE [34] significantly inhibits the mobility of monocytes expressing the CX3CR1-M280 variant [19]. If similar alterations occur in vivo to $\mathrm{MC} / \mathrm{M} \varphi$, the M280 polymorphism may cause excessive $\mathrm{MC} / \mathrm{M} \varphi$ adherence to membraneanchored CX3CL1 in the retina and RPE [34] and reduce migration in response to other inflammatory chemoattractants. In subjects with the M280 polymorphism, clearance of $\mathrm{MC} / \mathrm{M} \varphi \mathrm{s}$ from the subretinal space (in response to soluble CX3CL1 or other chemoattractants) would thereby be inhibited, and subretinal $\mathrm{MC} / \mathrm{M} \varphi$ accumulation might occur.

The prolonged presence of subretinal $\mathrm{MC} / \mathrm{M} \varphi$ s could thereby lead to subretinal drusenoid deposits, retinal and RPE degeneration, and an increase in CNV as observed in $\mathrm{Cx} 3 \mathrm{Cr}^{-1-}$ mice. These results suggest that $\mathrm{MC} / \mathrm{M} \varphi$ accumulation in the subretinal space may be a driving force in the pathogenesis of AMD and not a mere consequence of primary RPE or photoreceptor disease.

\section{$\mathrm{Ccl}^{-/-}$and $\mathrm{Ccr}^{-/-}$mouse models of AMD}

There are several reports using $\mathrm{Ccl} 2^{-1-}$ or $\mathrm{Ccr} 2^{-1-}$ mice in an attempt to decipher the inflammatory mechanisms of AMD. CCL2 is increased intraocularly in exudative AMD [47] and in a mouse model of choroidal neovascularization [40]. Tsutsumi et al. [44] reported that macrophages extracted from eyes undergoing the laserinduced $\mathrm{CNV}$ model are angiogenic and that the recruitment of $\mathrm{MC} / \mathrm{M} \varphi$ s to the injury site and subsequent $\mathrm{CNV}$ are reduced in $\mathrm{Ccr} 2^{-1-}$ mice. These results have since been corroborated in $\mathrm{Ccl} 2^{-/-}$mice [45]. Supporting this data is the repeated observation that macrophage depletion inhibits CNV [24,66]. In contrast, Ambati et al. observed spontaneous $\mathrm{CNV}$ in 4 of $15 \mathrm{Ccl}^{2 /-}$ and 3 in $13 \mathrm{Ccr}^{-/-}$mice older than 18 months of age, identified by angiographic leakage. Luhmann et al. were unable to detect spontaneous CNV by angiography or immunohistochemistry in $11 \mathrm{Ccl}^{-1-}$ mice aged 16 to 25 months [45], suggesting that CCL2 deficiency is not sufficient to induce spontaneous neovascularization. Ambati et al. also observed the spontaneous appearance of yellowish white subretinal deposits in fundoscopies of $\mathrm{Ccl} 2^{-1-}$ and $\mathrm{Ccr} 2^{-1-}$ mice aged 9 months and older, which they referred to as "drusen". The authors suggested that the deficiency in $\mathrm{M} \varphi$ recruitment through a CCL2-/CCR2-dependent pathway from choroidal circulation may prevent the clearance of accumulating debris in BM [25], which, over time, would lead to drusen formation. Luhmann et al. corroborated the spontaneous appearance of funduscopically observed autofluorescent lesions that resemble drusen in 16- to 25-month-old $\mathrm{Ccl}^{-1-}$ mice. However, these lesions are not caused by the sub-RPE extracellular deposits believed to be the origin of drusen appearance in humans. In fact, the anatomical equivalent of the lesions observed in $\mathrm{Ccl}_{2}^{-1-}$ mice was found to be bloated subretinal lipid MC/M $\varphi s$ detectable by immunohistochemistry [45], similar to those described in $\mathrm{Cx} 3 \mathrm{cr}^{-1-}$ mice $[19,56]$. It is difficult to appreciate what structure led to the drusen-like lesions described by Ambati et al. [25] because immunohistochemical analysis of subretinal $\mathrm{MC} / \mathrm{M} \varphi$ s were not performed and no histological evidence of typical convex shaped local BM deposits are shown.

In terms of photoreceptor degeneration Ambati et al. [25], using electron microscopy, observed pyknotic photoreceptor cell nuclei in 16-month-old $\mathrm{Ccl}^{-1-}$ mice but not in wild type animals. Nevertheless, the quantification of photoreceptor in 23- to 25-month-old mice performed by Luhmann et al. [45] showed no significant degeneration in $\mathrm{Ccl}_{2}{ }^{-1-}$ mice as compared to wild type congeners, suggesting that $\mathrm{Ccl} 2$ invalidation does not lead to significant photoreceptor degeneration.

The conclusion drawn from Ambati's data [25], that AMD develops because of a CCR2-dependent macrophage recruitment deficit and therefore a hypoinflammatory state, is in contradiction with a recent report of increased intraocular CCL2 levels in AMD [47] and abundant evidence of $\mathrm{MC} / \mathrm{M} \varphi$ accumulation in AMD [9,19-21]. Further studies are needed to identify the additional factors that led to the discrepancy of Luhmann et al.'s and Ambati et al.'s results.

\section{The $\mathrm{Ccl}^{-1-} \mathrm{C} \times 3 \mathrm{Cr}^{-/-}$mouse model of AMD}

Tuo et al. [37] were the first to describe an association between the T280M Cx3cr1 allele and AMD in 2004. Shortly thereafter, Ambati et al. [25] reported that $\mathrm{Ccl}_{2}{ }^{-1-}$ and $\mathrm{Ccr} 2^{-1-}$ mice develop AMD-like features at an advanced age. In an attempt to accelerate the development of AMD-like features, Tuo et al. [67] generated $\mathrm{Ccl}^{-1-} \mathrm{Cx} 3 \mathrm{cr}^{-1-}$ mice that indeed develop "drusen," pigment alterations, and retinal degeneration by the age of 6 weeks in 100\% of mice. Nevertheless, independently generated $\mathrm{Ccl}^{-1-} \mathrm{Cx} 3 \mathrm{cr}^{-/-}$mice in our laboratory do not present any of these features at 6 weeks of age, and are indistinguishable from $\mathrm{Ccl}_{2}^{-1-}, \mathrm{Cx} 3 \mathrm{Cr}^{-1-}$ and wild type animals. Tuo and Chan [68] also reported an abnormal mendelian segregation of the $\mathrm{Ccl} 2^{-1-} \mathrm{Cx} 3 \mathrm{cr}^{-1-}$ genotype, poor reproduction, and progressive patchy skin depigmentation, all of which we have not encountered in the generation of our $\mathrm{Ccl}^{2-{ }^{-} \mathrm{Cx} 3 \mathrm{cr} 1^{-1-}}$ mice [29]. Tuo et al. [68] selected the founding breeding pair of their $\mathrm{Ccl}^{-1-}$ 
$\mathrm{Cx} 3 \mathrm{cr}^{-1-}$ mice "with the most retinal drusen-like lesions". By selecting the founding breeding pair for AMD-like features, the authors may have selected animals genetically predisposed to these lesions independent of their Ccl2 or Cx3cr1 invalidation. The nonreproducibility of the ocular and systemic features in our $\mathrm{Ccl}^{-1-} \mathrm{Cx} 3 \mathrm{Cr}^{-1-}$ mice, in which the breeding pairs were not selected for any feature other than the genetic invalidation of $\mathrm{Ccl} 2$ and $\mathrm{Cx} 3 \mathrm{cr} 1$, suggests this is the case. The conclusions concerning the implication of CCL2 in the phenotype of this mouse strain should therefore be taken with caution.

\section{Conclusions and perspectives}

CX3CL1 and CX3CR1 are robustly expressed in the healthy retina. Their dysfunction leads to subretinal $\mathrm{MC} / \mathrm{M} \varphi$ accumulation with deleterious effects to the RPE and photoreceptors. The association of AMD with a polymorphism in the $\mathrm{Cx} 3 \mathrm{cr} 1$ gene, leading to a dysfunctional CX3CR1 protein, and the observation that $\mathrm{MC} / \mathrm{M} \varphi \mathrm{s}$ accumulate in the subretinal space in AMD suggests that dysfunctional CX3CL1/CX3CR1 signaling might play a role in the pathogenesis of AMD. However, the mechanism that leads to the $\mathrm{MC} / \mathrm{M} \varphi$ accumulation remains obscure and further research is needed to identify the implicated actors.

In contrast, CCL2 and CCR2 expression in the healthy retina is low. Injuries, such as laser impacts or retinal detachment, lead to a CCL2/CCR2 dependent recruitment of $\mathrm{MC} / \mathrm{M} \varphi$ to the subretinal space with deleterious effects to the photoreceptors and to the progression of $\mathrm{CNV}[23,44]$. A recent clinical study that shows an association of increased intraocular CCL2 levels and AMD [47] supports the possible involvement of CCL2 in the pathogenesis of AMD. It is not well understood if CCR2 is expressed in the healthy retina. The observation that $\mathrm{Ccl}^{-1-}$ mice also develop subretinal MC/M $\mathrm{M}$ accumulation at a later stage might indicate an age-dependent shift in populations of CX3CR1 + CCR2- microglia to CX3CR1 + CCR2 + microglia and that at this later stage, CCL2/CCR2 signaling is implicated in the clearance of subretinal $\mathrm{MC} / \mathrm{M} \varphi \mathrm{s}$ similar to the phenomenon observed in $\mathrm{Cx}_{3} \mathrm{cr}^{-1-}$ mice. These results would suggest that the inhibition of CCL2/CCR2 signaling might have a beneficial effect on CNV formation and MC/M $\varphi$ associated photoreceptor degeneration at an early stage of AMD. More research is needed to determine if CCL2/ CCR2 inhibition is beneficial at a later stage.

\section{Acknowledgements}

This work was supported by grants from INSERM, ANR "blanc" (AO5120DD), European Grant "Innochem" (LSHB-CT-2005-518167), ANR "Maladies Neurologiques et Maladies Psychiatriques" (R08098DS) and ERC starting Grant (ERC-2007 St.G. 210345). C.C. and F.S. are recipients of a contract «
Interface » from Assistance Publique-Hopitaux de Paris. We thank Christopher Murray for critical review of the manuscript.

\section{Author details}

${ }^{1}$ INSERM, UMR S 872, Centre de Recherche des Cordeliers, F-75006, Paris, France. '2UPMC Univ Paris 06, UMR S 872, F-75006, Paris, France. ${ }^{3}$ Université Paris Descartes, UMR S 872, F-75006, Paris, France. ${ }^{4}$ INSERM, UMR_S945, Laboratoire d'Immunologie Cellulaire, F-75013, Paris, France. ${ }^{5}$ UPMC Univ Paris 06, UMR 5945, F-75006, Paris, France. ${ }^{6}$ AP-HP, Groupe hospitalier PitiéSalpétrière, Service d'Immunologie, F-75013, Paris, France. ${ }^{7} A P-H P$, Hôtel Dieu, Service d'Ophtalmologie, F-75001, Paris, France.

\section{Authors' contributions}

WR, CA, SC, XG, CF and CC contributed to the writing of different sections of the manuscript. FS wrote the manuscript. All authors have read and approved the final version of the manuscript.

\section{Competing interests}

The authors declare that they have no competing interests.

Received: 20 October 2010 Accepted: 2 December 2010

Published: 2 December 2010

\section{References}

1. Klein R, Peto T, Bird A, Vannewkirk MR: The epidemiology of age-related macular degeneration. Am J Ophthalmol 2004, 137:486-495.

2. Sarks SH: Ageing and degeneration in the macular region: a clinicopathological study. Br J Ophthalmol 1976, 60:324-341.

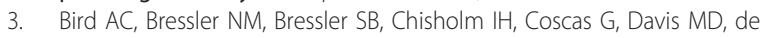
Jong PT, Klaver CC, Klein BE, Klein R, et al: An international classification and grading system for age-related maculopathy and age-related macular degeneration. The International ARM Epidemiological Study Group. Surv Ophthalmol 1995, 39:367-374.

4. Farkas TG, Sylvester V, Archer D: The ultrastructure of drusen. Am J Ophthalmol 1971, 71:1196-1205.

5. Hageman GS, Luthert PJ, Victor Chong NH, Johnson LV, Anderson DH, Mullins RF: An integrated hypothesis that considers drusen as biomarkers of immune-mediated processes at the RPE-Bruch's membrane interface in aging and age-related macular degeneration. Prog Retin Eye Res 2001, 20:705-732.

6. Klein R, Klein BE, Knudtson MD, Meuer SM, Swift M, Gangnon RE: Fifteenyear cumulative incidence of age-related macular degeneration: the Beaver Dam Eye Study. Ophthalmology 2007, 114:253-262.

7. van Leeuwen R, Klaver CC, Vingerling JR, Hofman A, de Jong PT: The risk and natural course of age-related maculopathy: follow-up at $61 / 2$ years in the Rotterdam study. Arch Ophthalmol 2003, 121:519-526.

8. Ramkumar HL, Zhang J, Chan CC: Retinal ultrastructure of murine models of dry age-related macular degeneration (AMD). Prog Retin Eye Res 2010, 29:169-190.

9. van der Schaft TL, Mooy CM, de Bruijn WC, de Jong PT: Early stages of age-related macular degeneration: an immunofluorescence and electron microscopy study. Br J Ophthalmol 1993, 77:657-661.

10. Mullins RF, Russell SR, Anderson DH, Hageman GS: Drusen associated with aging and age-related macular degeneration contain proteins common to extracellular deposits associated with atherosclerosis, elastosis, amyloidosis, and dense deposit disease. FASEB J 2000, 14:835-846.

11. Luibl V, Isas JM, Kayed R, Glabe CG, Langen R, Chen J: Drusen deposits associated with aging and age-related macular degeneration contain nonfibrillar amyloid oligomers. J Clin Invest 2006, 116:378-385.

12. Johnson LV, Leitner WP, Staples MK, Anderson DH: Complement activation and inflammatory processes in Drusen formation and age related macular degeneration. Exp Eye Res 2001, 73:887-896.

13. Edwards AO, Ritter R, Abel KJ, Manning A, Panhuysen C, Farrer LA Complement factor $\mathrm{H}$ polymorphism and age-related macular degeneration. Science 2005, 308:421-424.

14. Haines JL, Hauser MA, Schmidt S, Scott WK, Olson LM, Gallins P, Spencer KL, Kwan SY, Noureddine M, Gilbert JR, et al: Complement factor $\mathrm{H}$ variant increases the risk of age-related macular degeneration. Science 2005, 308:419-421.

15. Klein RJ, Zeiss C, Chew EY, Tsai JY, Sackler RS, Haynes C, Henning AK, SanGiovanni JP, Mane SM, Mayne ST, et al: Complement factor H 
polymorphism in age-related macular degeneration. Science 2005 308:385-389.

16. Ormsby RJ, Ranganathan S, Tong JC, Griggs KM, Dimasi DP, Hewitt AW, Burdon KP, Craig JE, Hoh J, Gordon DL: Functional and structural implications of the complement factor $\mathrm{H} Y 402 \mathrm{H}$ polymorphism associated with age-related macular degeneration. Invest Ophthalmol Vis Sci 2008, 49:1763-1770.

17. Hakobyan $\mathrm{S}$, Harris $\mathrm{CL}$, van den Berg CW, Fernandez-Alonso MC, de Jorge EG, de Cordoba SR, Rivas G, Mangione P, Pepys MB, Morgan BP: Complement factor $\mathrm{H}$ binds to denatured rather than to native pentameric C-reactive protein. J Biol Chem 2008, 283:30451-30460.

18. Xu H, Chen M, Forrester JV: Para-inflammation in the aging retina. Prog Retin Eye Res 2009, 28:348-368.

19. Combadiere C, Feumi C, Raoul W, Keller N, Rodero M, Pezard A, Lavalette S, Houssier M, Jonet L, Picard E, et al: CX3CR1-dependent subretinal microglia cell accumulation is associated with cardinal features of agerelated macular degeneration. J Clin Invest 2007, 117:2920-2928.

20. Penfold PL, Liew SC, Madigan MC, Provis JM: Modulation of major histocompatibility complex class II expression in retinas with age-related macular degeneration. Invest Ophthalmol Vis Sci 1997, 38:2125-2133.

21. Gupta N, Brown KE, Milam AH: Activated microglia in human retinitis pigmentosa, late-onset retinal degeneration, and age-related macular degeneration. Exp Eye Res 2003, 76:463-471.

22. Nozaki M, Raisler BJ, Sakurai E, Sarma JV, Barnum SR, Lambris JD, Chen Y, Zhang K, Ambati BK, Baffi JZ, Ambati J: Drusen complement components C3a and C5a promote choroidal neovascularization. Proc Natl Acad Sci USA 2006, 103:2328-2333

23. Nakazawa T, Hisatomi T, Nakazawa C, Noda K, Maruyama K, She H, Matsubara A, Miyahara S, Nakao S, Yin Y, et al: Monocyte chemoattractant protein 1 mediates retinal detachment-induced photoreceptor apoptosis. Proc Natl Acad Sci USA 2007, 104:2425-2430.

24. Espinosa-Heidmann DG, Suner IJ, Hernandez EP, Monroy D, Csaky KG, Cousins SW: Macrophage depletion diminishes lesion size and severity in experimental choroidal neovascularization. Invest Ophthalmol Vis Sci 2003, 44:3586-3592.

25. Ambati J, Anand A, Fernandez S, Sakurai E, Lynn BC, Kuziel WA, Rollins BJ, Ambati BK: An animal model of age-related macular degeneration in senescent CCl-2- or Ccr-2-deficient mice. Nat Med 2003, 9:1390-1397.

26. Yi X, Ogata N, Komada M, Yamamoto C, Takahashi K, Omori K, Uyama M: Vascular endothelial growth factor expression in choroidal neovascularization in rats. Graefes Arch Clin Exp Ophthalmol 1997, 235:313-319.

27. Ishibashi T, Hata Y, Yoshikawa H, Nakagawa K, Sueishi K, Inomata H: Expression of vascular endothelial growth factor in experimental choroidal neovascularization. Graefes Arch Clin Exp Ophthalmol 1997, 235:159-167.

28. Luster AD: Chemokines-chemotactic cytokines that mediate inflammation. N Engl J Med 1998, 338:436-445.

29. Combadiere C, Potteaux S, Rodero M, Simon T, Pezard A, Esposito B, Merval R, Proudfoot A, Tedgui A, Mallat Z: Combined inhibition of CCL2, CX3CR1, and CCR5 abrogates Ly6C(hi) and Ly6C(lo) monocytosis and almost abolishes atherosclerosis in hypercholesterolemic mice. Circulation 2008, 117:1649-1657.

30. Combadiere C, Potteaux S, Gao JL, Esposito B, Casanova S, Lee EJ, Debre P, Tedgui A, Murphy PM, Mallat Z: Decreased atherosclerotic lesion formation in CX3CR1/apolipoprotein E double knockout mice. Circulation 2003, 107:1009-1016

31. Geissmann F, Jung S, Littman DR: Blood monocytes consist of two principal subsets with distinct migratory properties. Immunity 2003, 19:71-82.

32. Bazan JF, Bacon KB, Hardiman G, Wang W, Soo K, Rossi D, Greaves DR Zlotnik A, Schall TJ: A new class of membrane-bound chemokine with a CX3C motif. Nature 1997, 385:640-644.

33. Ransohoff RM: Chemokines and chemokine receptors: standing at the crossroads of immunobiology and neurobiology. Immunity 2009, 31:711-721.

34. Silverman MD, Zamora DO, Pan Y, Texeira PV, Baek SH, Planck SR, Rosenbaum JT: Constitutive and inflammatory mediator-regulated fractalkine expression in human ocular tissues and cultured cells. Invest Ophthalmol Vis Sci 2003, 44:1608-1615.
35. Checchin D, Sennlaub F, Levavasseur E, Leduc M, Chemtob S: Potential role of microglia in retinal blood vessel formation. Invest Ophthalmol Vis Sci 2006, 47:3595-3602.

36. Jung S, Aliberti J, Graemmel P, Sunshine MJ, Kreutzberg GW, Sher A, Littman DR: Analysis of fractalkine receptor CX(3)CR1 function by targeted deletion and green fluorescent protein reporter gene insertion. Mol Cell Biol 2000, 20:4106-4114.

37. Tuo J, Smith BC, Bojanowski CM, Meleth AD, Gery I, Csaky KG, Chew EY, Chan CC: The involvement of sequence variation and expression of CX3CR1 in the pathogenesis of age-related macular degeneration. Faseb J 2004, 18:1297-1299.

38. Chen H, Liu B, Lukas TJ, Neufeld AH: The aged retinal pigment epithelium/choroid: a potential substratum for the pathogenesis of agerelated macular degeneration. PLoS One 2008, 3:e2339.

39. de Vos AF, Klaren VN, Kijlstra A: Expression of multiple cytokines and IL1RA in the uvea and retina during endotoxin-induced uveitis in the rat. Invest Ophthalmol Vis Sci 1994, 35:3873-3883.

40. Yamada K, Sakurai E, Itaya M, Yamasaki S, Ogura Y: Inhibition of laserinduced choroidal neovascularization by atorvastatin by downregulation of monocyte chemotactic protein-1 synthesis in mice. Invest Ophthalmol Vis Sci 2007, 48:1839-1843.

41. Higgins GT, Wang JH, Dockery P, Cleary PE, Redmond HP: Induction of angiogenic cytokine expression in cultured RPE by ingestion of oxidized photoreceptor outer segments. Invest Ophthalmol Vis Sci 2003, 44:1775-1782.

42. Ma W, Zhao L, Fontainhas AM, Fariss RN, Wong WT: Microglia in the mouse retina alter the structure and function of retinal pigmented epithelial cells: a potential cellular interaction relevant to AMD. PLoS One 2009, 4:e7945

43. Charo IF, Myers SJ, Herman A, Franci C, Connolly AJ, Coughlin SR: Molecular cloning and functional expression of two monocyte chemoattractant protein 1 receptors reveals alternative splicing of the carboxyl-terminal tails. Proc Natl Acad Sci USA 1994, 91:2752-2756.

44. Tsutsumi C, Sonoda KH, Egashira K, Qiao H, Hisatomi T, Nakao S, Ishibashi M, Charo IF, Sakamoto T, Murata T, Ishibashi T: The critical role of ocular-infiltrating macrophages in the development of choroidal neovascularization. J Leukoc Biol 2003, 74:25-32.

45. Luhmann UF, Robbie S, Munro PM, Barker SE, Duran Y, Luong V, Fitzke FW, Bainbridge JW, Ali RR, MacLaren RE: The drusenlike phenotype in aging Ccl2-knockout mice is caused by an accelerated accumulation of swollen autofluorescent subretinal macrophages. Invest Ophthalmol Vis Sci 2009, 50:5934-5943.

46. Eltayeb S, Berg AL, Lassmann H, Wallstrom E, Nilsson M, Olsson T, EricssonDahlstrand A, Sunnemark D: Temporal expression and cellular origin of CC chemokine receptors CCR1, CCR2 and CCR5 in the central nervous system: insight into mechanisms of MOG-induced EAE. $J$ Neuroinflammation 2007, 4:14.

47. Jonas JB, Tao Y, Neumaier M, Findeisen P: Monocyte chemoattractant protein 1 , intercellular adhesion molecule 1 , and vascular cell adhesion molecule 1 in exudative age-related macular degeneration. Arch Ophthalmol 2010, 128:1281-1286.

48. Yang X, Hu J, Zhang J, Guan H: Polymorphisms in CFH, HTRA1 and CX3CR1 confer risk to exudative age-related macular degeneration in Han Chinese. Br J Ophthalmol

49. McDermott DH, Fong AM, Yang Q, Sechler JM, Cupples LA, Merrell MN, Wilson PW, D'Agostino RB, O'Donnell CJ, Patel DD, Murphy PM: Chemokine receptor mutant CX3CR1-M280 has impaired adhesive function and correlates with protection from cardiovascular disease in humans. J Clin Invest 2003, 111:1241-1250.

50. Daoudi M, Lavergne E, Garin A, Tarantino N, Debre P, Pincet F, Combadiere C, Deterre P: Enhanced adhesive capacities of the naturally occurring lle249-Met280 variant of the chemokine receptor CX3CR1. J Biol Chem 2004, 279:19649-19657.

51. Despriet DD, Bergen AA, Merriam JE, Zernant J, Barile GR, Smith RT, Barbazetto IA, van Soest S, Bakker A, de Jong PT, et al: Comprehensive analysis of the candidate genes CCL2, CCR2, and TLR4 in age-related macular degeneration. Invest Ophthalmol Vis Sci 2008, 49:364-371.

52. Liang KJ, Lee JE, Wang YD, Ma W, Fontainhas AM, Fariss RN, Wong WT: Regulation of dynamic behavior of retinal microglia by CX3CR1 signaling. Invest Ophthalmol Vis Sci 2009, 50:4444-4451. 
53. Raoul W, Keller N, Rodero M, Behar-Cohen F, Sennlaub F, Combadiere C Role of the chemokine receptor CX3CR1 in the mobilization of phagocytic retinal microglial cells. J Neuroimmunol 2008, 198:56-61.

54. Xu H, Chen M, Manivannan A, Lois N, Forrester JV: Age-dependent accumulation of lipofuscin in perivascular and subretinal microglia in experimental mice. Aging Cell 2008, 7:58-68

55. Ng TF, Streilein JW: Light-induced migration of retinal microglia into the subretinal space. Invest Ophthalmol Vis Sci 2001, 42:3301-3310.

56. Raoul W, Feumi C, Keller N, Lavalette S, Houssier M, Behar-Cohen F, Combadiere C, Sennlaub F: Lipid-bloated subretinal microglial cells are at the origin of drusen appearance in CX3CR1-deficient mice. Ophthalmic Res 2008, 40:115-119.

57. Rudolf M, Malek G, Messinger JD, Clark ME, Wang L, Curcio CA: Sub-retinal drusenoid deposits in human retina: organization and composition. Exp Eye Res 2008, 87:402-408.

58. Zweifel SA, Imamura Y, Spaide TC, Fujiwara T, Spaide RF: Prevalence and Significance of Subretinal Drusenoid Deposits (Reticular Pseudodrusen) in Age-Related Macular Degeneration. Ophthalmology 2010.

59. Cohen SY, Dubois L, Tadayoni R, Delahaye-Mazza C, Debibie C, Quentel G: Prevalence of reticular pseudodrusen in age-related macular degeneration with newly diagnosed choroidal neovascularisation. $\mathrm{Br} J$ Ophthalmol 2007, 91:354-359.

60. Xu Q, Bernardo A, Walker D, Kanegawa T, Mahley RW, Huang Y: Profile and regulation of apolipoprotein $E$ (ApoE) expression in the CNS in mice with targeting of green fluorescent protein gene to the ApoE locus. $J$ Neurosci 2006, 26:4985-4994.

61. Bellander BM, Bendel O, Von Euler G, Ohlsson M, Svensson M: Activation of microglial cells and complement following traumatic injury in rat entorhinal-hippocampal slice cultures. J Neurotrauma 2004, 21:605-615.

62. Matsubara T, Pararajasegaram G, Wu GS, Rao NA: Retinal microglia differentially express phenotypic markers of antigen-presenting cells in vitro. Invest Ophthalmol Vis Sci 1999, 40:3186-3193.

63. Joly $S$, Francke $M$, Ulbricht $E$, Beck $S$, Seeliger $M$, Hirrlinger $P$, Hirrlinger J, Lang KS, Zinkernagel M, Odermatt B, et al: Cooperative phagocytes: resident microglia and bone marrow immigrants remove dead photoreceptors in retinal lesions. Am J Pathol 2009, 174:2310-2323.

64. Roque RS, Rosales AA, Jingjing L, Agarwal N, Al-Ubaidi MR: Retina-derived microglial cells induce photoreceptor cell death in vitro. Brain Res 1999, 836:110-119

65. Cardona AE, Pioro EP, Sasse ME, Kostenko V, Cardona SM, Dijkstra IM, Huang D, Kidd G, Dombrowski S, Dutta R, et al: Control of microglial neurotoxicity by the fractalkine receptor. Nat Neurosci 2006, 9:917-924.

66. Sakurai E, Anand A, Ambati BK, van Rooijen N, Ambati J: Macrophage depletion inhibits experimental choroidal neovascularization. Invest Ophthalmol Vis Sci 2003, 44:3578-3585.

67. Tuo J, Bojanowski CM, Zhou M, Shen D, Ross RJ, Rosenberg KI, Cameron DJ, Yin C, Kowalak JA, Zhuang Z, et al: Murine $\mathrm{ccl} 2 / \mathrm{cx} 3 \mathrm{cr} 1$ deficiency results in retinal lesions mimicking human age-related macular degeneration. Invest Ophthalmol Vis Sci 2007, 48:3827-3836.

68. Chan CC, Ross RJ, Shen D, Ding X, Majumdar Z, Bojanowski CM, Zhou M, Salem N Jr, Bonner R, Tuo J: Ccl2/Cx3cr1-deficient mice: an animal model for age-related macular degeneration. Ophthalmic Res 2008, 40:124-128.

doi:10.1186/1742-2094-7-87

Cite this article as: Raoul et al:: CCL2/CCR2 and CX3CL1/CX3CR1

chemokine axes and their possible involvement in age-related macular degeneration. Journal of Neuroinflammation 2010 7:87.

\section{Submit your next manuscript to BioMed Central and take full advantage of:}

- Convenient online submission

- Thorough peer review

- No space constraints or color figure charges

- Immediate publication on acceptance

- Inclusion in PubMed, CAS, Scopus and Google Scholar

- Research which is freely available for redistribution

Submit your manuscript at www.biomedcentral.com/submit 